УДК 351.712

DOI https://doi.org/10.32838/TNU-2663-6468/2020.4/20

\title{
Пророчук М.В.
}

Національна академія державного управління при Президентові України

\section{МЕХАНІЗМ ВЗАЕМОДІЇ ВЛАДИ ТА БІЗНЕСУ У СФЕРІ ІНФРАСТРУКТУРИ}

У статті розглянуто особливості взаємодї влади й бізнесу у сфері інфраструктури, визначені ключові учасники й інструменти ефективної взаємодії влади й бізнесу: поновлення стабільності в макроекономіці, викладення покращених умов для господарської діяльності й прозорої податкової системи. Визначено основні нормативні акти, які регулюють державноприватне партнерство в Україні, думки вчених на таку категорію. Виявлено, що основними формами співпращі держави й бізнесу є концесія, управління майном і спільна діяльність на підставі договору й на засадах проєктного фінансування. Схарактеризовано ризики й переваги спільної взаємодії для влади й бізнесу у сфері інфраструктури. Перераховані базові моделі взаємодії влади й бізнесу: модель оператора, модель кооперачії, модель кониесії, модель договірна, модель лізингу. Визначено, що основними документами, що регулюють відносини державно-приватного партнерства, є Концепиія розвитку державно-приватного партнерства в Україні на 2013-2018 рр. і Меморандум про взаємодію між Мінекономрозвитку й Міжнародною фінансовою корпорачією Світового банку. Зазначено кількість проєктів державноприватного партнерства в Украйні за областями на сучасному етапі, усього на засадах державно-приватного партнерства укладено 187 договорів. Досліджено рейтинг топінвесторів у вітчизняні проєкти державно-приватного партнерства за останні 15 років. Розроблено механізм взаємодї влади й бізнесу у сфері інфраструктури, до якого входять суб'єкти, етапи, інструменти й нові форми взаємодї влади й бізнесу. Досліджено проблеми й перешкоди державно-приватного партнерства в сучасних умовах, а також заходи, необхідні для розвитку механізму взаємодії влади й бізнесу у сфері інфраструктури, основними з яких є: політична й економічна зачікавленість держави; розробка проєктів, трунтовне опраџювання контрактів і можливостей фінансування; вдосконалення правової та економічної підготовки суб'єктів виконавчої влади, сприяння їх готовності йти на компроміси й знаходити шляхи розв 'язання утворюваних питань.

Ключові слова: механізм взаємодії влади й бізнесу, держсавно-приватне партнерство, конкурентоспроможність економіки, сфера інфраструктури, інструменти взаємодії, приватний сектор, держава.

Постановка проблеми. У сучасних умовах вітчизняна економіка й суспільство функціонує як суспільно-політична система, яка потребує комплексної взаємодії суспільства, бізнесу й держави. Влада розраховує, що бізнес здатен розв'язати нагальні проблеми економіки, а суспільні інститути - соціально-економічні проблеми. Саме тому владі необхідно розробити нову систему, ідеї, механізми й форми суспільного й політичного життя, що зможуть сприяти системному самовдосконаленню суспільства й бізнесу для розвитку держави. Сучасні форми взаємодії влади й бізнесу особливо необхідні у сфері інфраструктури, тому що саме цей напрямок у сучасних умовах не відповідає вимогам суспільства щодо якості життя, нових можливостей для розвитку й різноманіття отриманих послуг. Все це дає змогу стверджувати, що тема дослідження є вкрай цікавою та актуальною.
Аналіз останніх досліджень та публікацій. Аспекти взаємодії влади й бізнесу досліджувались багатьма іноземними: Дж. Гэлбрейтом, М. Кейнсом, Р. Кембеллом, Макконеллом та іншими, а також вітчизняними вченими: О. Амошою, В. Варнавськиим, М. Дерябіною, С. Павлюком, Т. Приходько й іншими. Цікаві дослідження Е. Уайта, Ю. Шевчука, Є. Черевикова, І. Запатріної та О. Никифорука стосовно світового досвіду взаємодії влади й бізнесу на засадах державноприватного партнерства в різних сферах національної економіки, зокрема у сфері розвитку інфраструктури. Р. Тейлор, С. Осборне, О. Єгорова також вивчали механізми державно-приватного партнерства (далі - ДПП) розвинутих країн у сфері інфраструктури (будівництві автошляхів, телекомунікаціях, залізничному транспорті), а також у соціальній сфері. 
Виділення невирішених раніше частин загальної проблеми. Вивчаючи велику кількість досліджень та аналізуючи наукові розробки щодо теоретико-методологічних і практичних напрацювань стосовно розвитку взаємовідносин між владою та бізнесом, необхідно зазначити, що на сучасному етапі недостатніми є дослідження можливостей розвитку механізму ДПП в Україні. Саме тому подальші дослідження проблематики взаємодії бізнесу й влади доцільні саме в напрямку розвитку інфраструктури й викликані сучасними соціально-економічними процесами в суспільстві. Актуальне визначення питань застосування механізмів ДПП у різних галузях інфраструктури, розробка нормативно-правових основ впровадження та застосування механізмів ДПП в Україні, дослідження статистичних показників виконання проєктів ДПП із метою розвитку й покращення інфраструктури в умовах сталого економічного розвитку.

Метою статті $є$ дослідження та визначення сучасних форм взаємодії влади й бізнесу у сфері інфраструктури, розробка механізму й з'ясування можливостей його впровадження в Україні.

Виклад основного матеріалу. В сучасних умовах узгоджена взаємодія влади й бізнесу набуває важливого значення через забезпечення необхідного балансу інтересів учасників соціальноекономічного розвитку. Одним з основних засобів мобілізації наявних резервів соціально-економічного розвитку, підвищення конкурентоспроможності країни й рівня життя населення $є$ ефективна взаємодія влади й бізнесу, яку слід ототожнювати 3 державно-приватним партнерством - відносно новим явищем у світовому просторі.

У національній доповіді «Соціально-економічний потенціал сталого розвитку України та іiі регіонів» зазначено, що ключовими учасниками забезпечення сталого розвитку є:

- органи влади різного рівня (сфера розроблення, ухвалення та реалізації управлінських рішень);

- бізнес-структури (сфера господарської діяльності й економічного розвитку);

- громадянське суспільство (сфера громадської активності й самоорганізації, інститути громадянського суспільства);

- людина (сфера звичайного життя, повсякденні життєві практики) [1, с. 138].

Згідно зі Стратегією сталого розвитку «Україна-2020», основними інструментами взаємодії влади й бізнесу є: відновлення макроекономічної стабільності, забезпечення стійкого зростання економіки екологічно невиснажливим способом, створення сприятливих умов для ведення господарської діяльності й прозорої податкової системи [2].

У дослідженнях Національного інституту стратегічних досліджень при Президентові України зазначено, що нормативно-правова основа регулювання відносин ДПП в Україні $€$ ускладненою та забюрократизованою, що створює певні перепони для ефективного використання цього механізму.

Основні нормативні акти, які регулюють державно-приватне партнерство в Україні: Закони України «Про державно-приватне партнерство»; «Про угоди про розподіл продукції»; «Про концесії»; «Про оренду землі»; «Про концесії на будівництво та експлуатацію автомобільних доріг»; «Про особливості передачі в оренду чи концесію об'єктів централізованого водо-, теплопостачання і водовідведення, що перебувають у комунальній власності»; «Про оренду державного та комунального майна»; Постанови Кабінету Міністрів України «Про затвердження Порядку проведення розрахунку плати за експлуатаційну готовність автомобільної дороги, побудованої на умовах концесії»; «Про затвердження Методики розрахунку концесійних платежів»; «Про затвердження переліку об'єктів паливно-енергетичного комплексу права державної власності, які можуть надаватися в концесію»; «Про затвердження переліку об'єктів права державної власності у концесію» та інші [3].

У чинному законодавстві зазначено, що основними формами співпраці держави й бізнесу $є$ : концесія, управління майном (за умови зазначення в договорі інвестиційних зобов'язань приватного партнера) й спільна діяльність на підставі договору й на засадах проєктного фінансування (договори на оренду й лізинг, управління державним майном, угоди про розподіл продукції, контракт, державні закупівлі й інше).

Учасниками відносин ДПП має бути: сильний державний сектор, який може адаптуватись до нових викликів, фахівці управління контрактами й мережевим партнерством, а також приватний сектор, що може брати на себе відповідальність державних органів влади й органів місцевого самоврядування. Основною проблемою в процесі розвитку державно-приватного партнерства $€$ розробка процедур стимулювання цих відносин і створення нового типу державної та громадської експертизи, що дозволить відстежувати результативність проєктів [4, с. 15]. 
У Законі України «Про державно-приватне партнерство» воно визначається як співробітництво між державою, територіальними громадами в особі відповідних державних органів та органів місцевого самоврядування (державними партнерами) та юридичними особами, крім державних і комунальних підприємств, або фізичними особами - підприємцями (приватними партнерами), що здійснюється на основі договору в порядку, встановленому цим Законом та іншими законодавчими актами [5]. В. Варнавський визначає державно-приватне партнерство як інституційний та організаційний альянс між державою та бізнесом із метою реалізації національних і міжнародних, масштабних і локальних, але завжди суспільно значущих проєктів у широкому спектрі сфер діяльності: від розвитку стратегічно важливих галузей промисловості й науково-дослідних конструкторських робіт до забезпечення суспільних послуг [6]. На думку М. Джеррарда, партнерства створюються та діють на межі державного й приватного секторів господарства для надання населенню деяких громадських послуг, не бувши разом із тим не націоналізованими або приватизованими активами й послугами, за допомогою якого уряди можуть надавати послуги [7]. Згідно 3 державно-управлінським підходом, механізм державно-приватного партнерства ототожнюють із непрямою приватизацією [8].
На нашу думку, партнерство влади й бізнесу у сфері інфраструктури має розглядатись як співпраця для реалізації спільних проєктів між органами державної влади й приватним сектором, яка має основні ознаки: реалізація суспільно корисної місії (будівництво й експлуатація публічних споруд) 3 економічною та фінансовою відповідальністю держави на умовах взаємних ризиків влади й бізнесу. Ризики для органів влади й бізнесу в процесі їхньої взаємодії представлені в таблиці 1.

\section{Таблиця 1}

Ризики для влади й бізнесу при ДПП

\begin{tabular}{|l|l|}
\hline \multicolumn{1}{|c|}{ Ризики для влади } & \multicolumn{1}{c|}{ Ризики для бізнесу } \\
\hline - зміни в політиці й зако- & - зміни в курсах валют та \\
нодавстві; & інфляція; \\
- можливість втрати & - недосконалість проєктів \\
контролю над об’єктами & будівництва й неможли- \\
муніципальної та держав- & вість дотримання фінан- \\
ної власності; & сових зобов’язань; \\
- недостатня кваліфікація & - зниження попиту спо- \\
державних працівників та & живачів на наявні про- \\
їх партнерів, різні інтереси. & дукти й послуги. \\
\hline
\end{tabular}

Разом із тим доцільно виділити переваги такої взаємодії для інфраструктурної сфери (таблиця 2).

Базовими моделями взаємодії влади й бізнесу, що дозволять розв'язати соціально-економічні завдання розвитку необхідних галузей економіки у сучасних умовах, $€$ :

Таблиця 2

\section{Переваги ДПП для інфраструктурної сфери [9]}

\begin{tabular}{|c|c|c|}
\hline Переваги для держави & Переваги для бізнесу & Переваги для суспільства \\
\hline $\begin{array}{l}\text { - максимальна віддача на вкладені } \\
\text { кошти; } \\
\text { - підвищення ефективності управ- } \\
\text { ління інфраструктурою; } \\
\text { - зняття проєкту з балансу держави; } \\
\text { - концентрація інвестицій у клю- } \\
\text { чових для населення проєктах у } \\
\text { публічному секторі; } \\
\text { - передача частини ризиків приват- } \\
\text { ному сектору; } \\
\text { - швидша реалізація інфраструк- } \\
\text { турних проєктів шляхом залучення } \\
\text { коштів; } \\
\text { - запозичення в приватного сектора } \\
\text { кращих практик управління; } \\
\text { - стимулювання розвитку інновацій } \\
\text { через конкуренцію. }\end{array}$ & $\begin{array}{l}\text { - доступ до закритих сфер еконо- } \\
\text { міки (транспорту, житлово-кому- } \\
\text { нального господарства тощо); } \\
\text { - розширення можливостей для } \\
\text { отримання кредитів під проєкт від } \\
\text { вітчизняних та іноземних фінансо- } \\
\text { вих установ на основі державних } \\
\text { гарантій; } \\
\text { - сприяння взаємодії бізнесу з } \\
\text { органами влади шляхом участі в } \\
\text { проєкті; } \\
\text { - підвищення статусу проєкту шля- } \\
\text { хом участі в ньому держави; } \\
\text { - створення позитивного іміджу } \\
\text { компанії. }\end{array}$ & $\begin{array}{l}\text { - підвищення ефективності держав- } \\
\text { них антикризових програм; } \\
\text { - формування середовища довіри й } \\
\text { відкритості суспільства; } \\
\text { - нарощування потенціалу впливу } \\
\text { підприємств на розмір та якість } \\
\text { людського капіталу підприємств, } \\
\text { регіонів, територій; } \\
\text { - поліпшення якості послуг насе- } \\
\text { ленню, в тому числі щодо розвитку } \\
\text { транспортної інфраструктури; } \\
\text { - зниження фінансового наванта- } \\
\text { ження на платників податків; } \\
\text { - зниження обсягів споживання } \\
\text { паливно-енергетичних ресурсів; } \\
\text { - відповідність створених об'єктів } \\
\text { вимогам санітарно-гігієнічних, } \\
\text { радіаційних, екологічних, архітек- } \\
\text { турних та інших норм, встановле- } \\
\text { них законодавством України. }\end{array}$ \\
\hline
\end{tabular}


1. Модель оператора - характеризується чітким розподілом відповідальності між партнерами, контрольну функцію виконує держава, фінансування приватне.

2. Модель кооперації - партнерство реалізується через спільне підприємство держави 1 приватного партнера, фінансування державне або приватне.

3. Модель концесії - використовується переважно в галузях агропромислового комплексу (далі - АПК) із тривалим терміном реалізації інвестиційного проєкту, фінансування державне або приватне.

4. Модель договірна - доцільно використовувати в II сфері АПК, в якій інвестиції спрямовані на зниження поточних витрат, фінансування приватне.

5. Модель лізингу - доцільно використовувати для III сфери АПК, оскільки лізингова форма партнерства застосовується місцевими органами влади 3 приватними партнерами, фінансування державне або приватне $[10 ; 11]$.

Основним документом, що на сучасному етапі регулює відносини ДПП, є Концепція розвитку державно-приватного партнерства в Україні на 2013-2018 pр. (Розпорядження від 14 серпня 2013 р. № 739-р), в якій розглянуто проблему партнерства загалом, виокремлено причини його повільного розвитку й проблеми надання державної підтримки із цього приводу. А також Меморандум про взаємодію між Мінекономрозвитку й Міжнародною фінансовою корпорацією Світового банку, підписаний 20 травня 2019 р. першим віцепрем'єр-міністром України, в якому передбачено можливість одержання консультативної допомоги від іноземних експертів щодо активізації державно-приватного партнерства в Україні й забезпечення початку роботи Агенції [12]. Механізм взаємодії влади й бізнесу у сфері інфраструктури представимо на рис. 1.

За даними центральних і місцевих органів виконавчої влади в Україні станом на 01 січня 2020 р. на засадах ДПП укладено 187 договорів, які представлені на рис. 1, з них реалізується 52 договори (34 договори концесії, 16 договорів про спільну діяльність, 2 - інші договори), 135 договори не реалізується (4 договори - закінчено термін дії, 18 договорів - розірвано, 113 договорів - не виконується) (рис. 2) [15].

Згідно зі статистичними даними, кількість проєктів державно-приватного партнерства в Україні щороку зростає, але цей ринок перебуває лише на стадії становлення. У таблиці 3 представлені найбільші інвестори е вітчизняні проєкти ДПП за останні 15 років.

Ми вважаємо, що проблеми не в кількості укладених угод між державним і приватним партнерами, а в їх результативності й ефективності.

На думку А. Міцкана, в Україні існують такі проблеми фінансування проєктів ДПП:

- недостатність державного фінансування для покращання комунальної інфраструктури;

- нерозуміння ризиків комунальних підприємств комерційними банками;

- складність отримання гарантій і повернення інвестицій;

- складність запозичення коштів органами місцевого самоврядування;

- обережність приватних i портфельних інвесторів;

- високі відсотки за кредит;

- наслідки фінансової кризи й обмеженість доступного іноземного капіталу;

Топінвестори у вітчизняні проскти ДПП за останні роки [17]

Таблиця 3

\begin{tabular}{|l|l|c|c|}
\hline \multicolumn{1}{|c|}{ Компанія-спонсор } & \multicolumn{1}{|c|}{ Країна походження } & $\begin{array}{c}\text { Інвестиції } \\
\text { (млн дол. США) }\end{array}$ & Кількість просктів \\
\hline $\begin{array}{l}\text { System Capital Management (SCM } \\
\text { Group) }\end{array}$ & Україна & 2572 & 22 \\
\hline Activ Solar Holding & Австрія & 1095 & 9 \\
\hline CMA-CGM & Франція & 130 & 1 \\
\hline Brooklyn-Kiev Group & Україна & 130 & 1 \\
\hline Wind Park Novoazovskiy LLC & Україна & 118 & 2 \\
\hline Rosvodokanal (RVK) & Російська Федерація & 102 & 1 \\
\hline Infox & Україна & 100 & 11 \\
\hline Cagrill, Inc. & США & 77 & 1 \\
\hline Gaztek & Україна & 23 & 17 \\
\hline Refraction Asset Managment & Канада & & 2 \\
\hline
\end{tabular}




\section{Суб’скти плідної взаємодії:}

1. Торговельно-промислова палата України - недержавна неприбуткова самокерована організація, націлена на створення сприятливих умов для підприємницької діяльності, сприяння всебічному розвитку науково-технічних і торговельних зв'язків між українськими підприємцями та їхніми закордонними партнерами, представлення інтересів її членів із питань господарської діяльності як в Україні, так і поза ііі межами.

2. Проєктний офіс із розвитку державно-приватного партнерства, створений із метою активізації розвитку державно-приватного партнерства в Україні, відкрито у 2016 р. при Міністерстві інфраструктури України за підтримки Фонду “Western NIS Enterprise Fund” (“WNISEF”) (США).

3. Агенція 3 питань державно-приватного партнерства, відкрита в березні 2019 р., основною функцією якої є здійснення заходів, спрямованих на підготовку до реалізації в Україні якісних та інвестиційно-привабливих проєктів ДПП у різних сферах економіки, організація заходів, спрямованих на підвищення інституційної спроможності органів місцевого самоврядування у сфері ДПП.

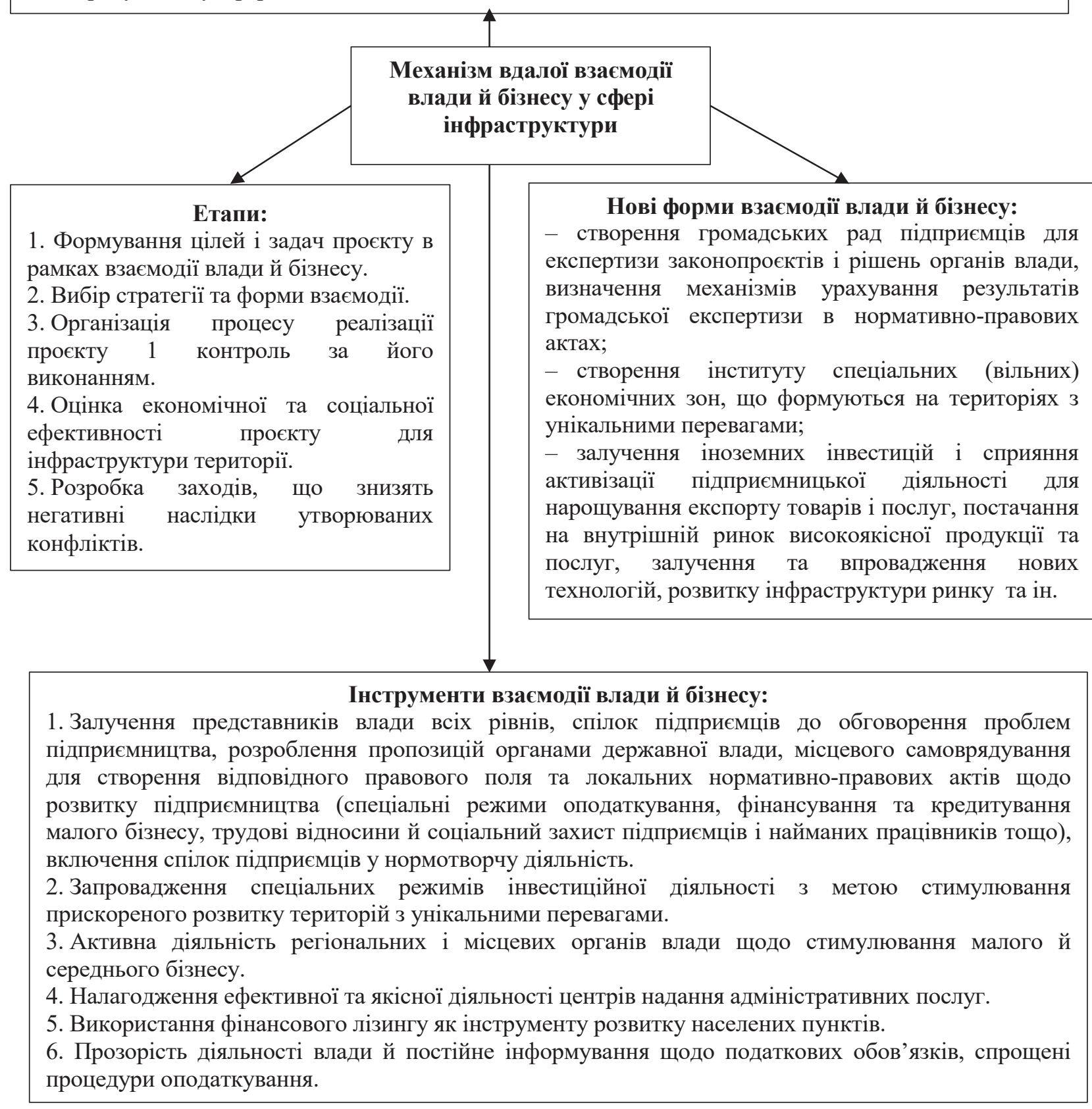

Рис. 1. Механізм взаємодії влади й бізнесу у сфері інфраструктури [13; 14] 


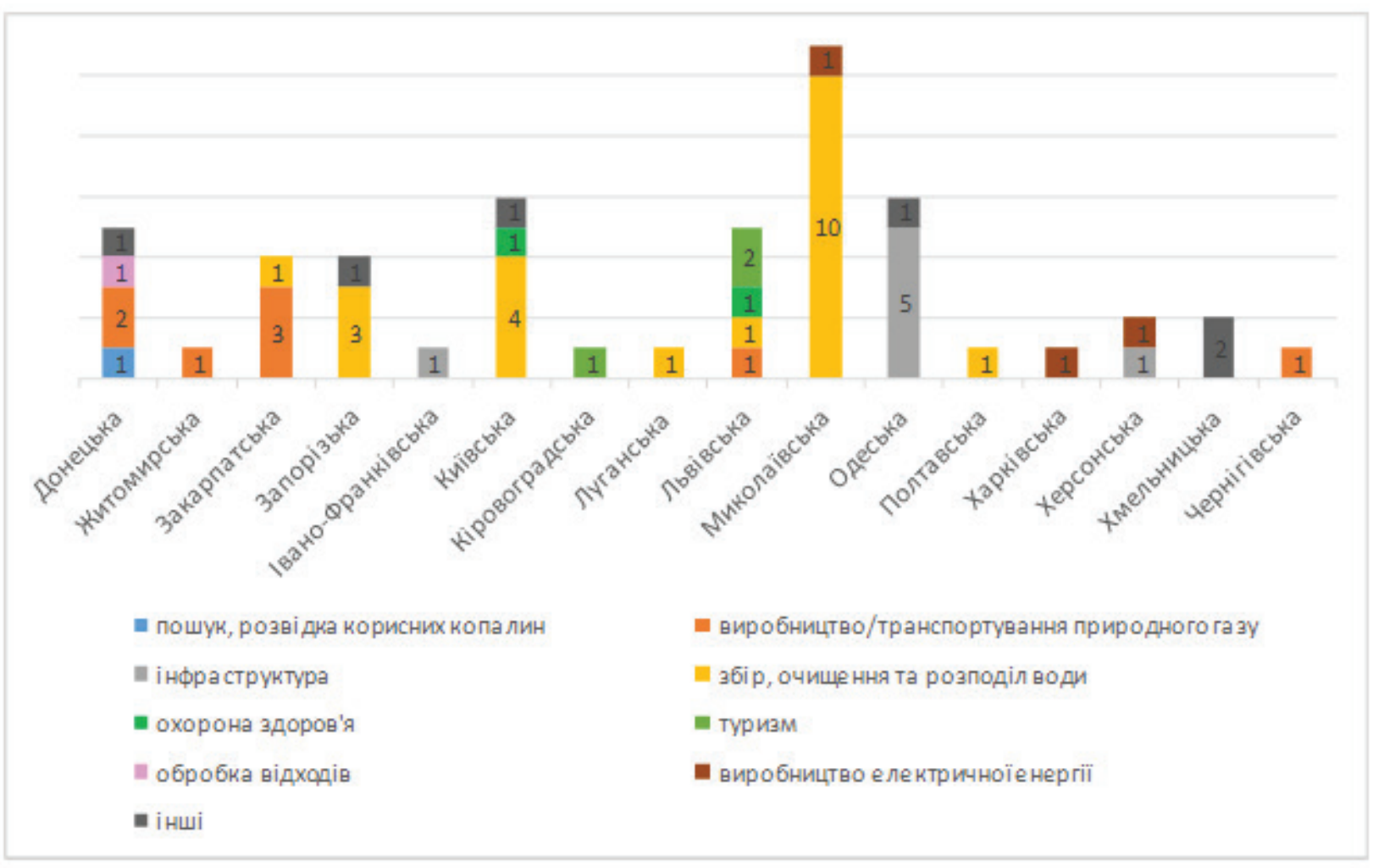

Рис. 2. Кількість проєктів ДПП в Україні за областями [15]

- проблеми гарантування постійних доходів для обслуговування позик [16, с. 6].

Вважаємо доцільним додати такі перешкоди на шляху активізації механізму взаємодії влади й бізнесу:

- недосконала регуляторна політика (непрозорість, високі тарифи й податки);

- відсутність необхідної інституційної інфраструктури;

- недостатня державна підтримка й недосконала нормативно-правова база.

На наш погляд, найдієвішими інструментами взаємодії влади й бізнесу, що підсилять конкурентні переваги країни загалом, мають стати:

- легкі вхідні бар'єри на ринок для бізнесу, зрозумілі правила реєстрації та короткі терміни оформлення документів;

- доступні приміщення та низькі податки;

- офіційні правила взаємодії, безперешкодне й вчасне отримання необхідних документів;

- впровадження європейського досвіду й стандартів.

Висновки та пропозиції. У сучасних умовах для взаємодії бізнесу й влади доцільно визначити стратегічні напрями, які дозволять покращити ці відносини:

1. Розробка ефективних механізмів впровадження проєктів ДПП на засадах оновленого нормативно-правового забезпечення.
2. Активізація діяльності держави, націленої на фінансову підтримку бізнесу й вдосконалення організаційно-адміністративних важелів.

3. Запровадження інноваційних заходів, які будуть сприяти мотивації бізнесу до спільних із державою проєктів.

4. Залучення нових інвестицій і реалізація інфраструктурних проєктів 3 активною участю малого й середнього бізнесу.

5. Максимальне використання ресурсів конкретної території (грунтових, природно-кліматичних, рекреаційних ресурсів) для покращення інфраструктури.

6. Використання досягнень науково-технічного прогресу для розвитку інвестицій та інновацій.

Для вдосконалення механізму взаємодії влади й бізнесу у сфері інфраструктури необхідні такі умови:

- політична й економічна зацікавленість держави;

- розробка драфтів проєктів, грунтовне опрацювання контрактів і можливостей фінансових ринків забезпечити їх фінансування;

- вдосконалення правової та економічної підготовки керівників і працівників органів виконавчої влади, сприяння готовності сторін йти на компроміси й знаходити шляхи розв'язання утворюваних питань. 


\section{Список літератури:}

1. Соціально-економічний потенціал сталого розвитку України та ії регіонів : національна доповідь / за ред. акад. НАН України Е.М. Лібанової, акад. НААН України М.А. Хвесика. Київ : ДУ ІЕПСР НАН України, 2014. 776 с.

2. Про Стратегію сталого розвитку «Україна - 2020» : Указ Президента України від 12 січня 2015 р. № 5/2015 / Верховна Рада України. URL: http://zakon3.rada.gov.ua/laws/show/5/2015.

3. Щодо розвитку державно-приватного партнерства як механізму активізації інвестиційної діяльності в Україні : аналітична записка. Національний інститут стратегічних досліджень : вебсайт. URL: http://www.niss.gov.ua/articles/816.

4. Практическое руководство по вопросам эффективного управления в сфере государственно-частного партнерства. Женева : Организация Объединенных Наций, 2008. 113 с.

5. Про державно-приватне партнерство : Закон України від 01 липня 2010 р. № 2404-VI / Верховна Рада України. Відомості Верховної Ради України. 2010. № 40. Ст. 524.

6. Варнавский В.Г. Концессии в транспортной инфраструктуре : теория, практика, перспективы. Москва : ИМЭМО РАН, 2002. 189 с.

7. Gerrard Michael B. What are public-private partnerships, and how do they differ from privatizations? Finance \& Development. 2001. Vol. 38. № 3. URL: http://www.imf.org/external/pubind.htm.

8. Public/Private Partnerships: Financing a Common Wealth. Wash., 1985. P. 67.

9. Крилова Н.В. Міжнародні стратегії розвитку державно-приватного партнерства в транспортній галузі. URL: http://www.sworld.com.ua/index.php/ru/conference/the-content-of-conferences/archives-ofindividual-conferences/march-2013.

10. Вінник О.М. Управління державно-приватним партнерством при використанні його акціонерної форми. Вісник Академії правових наук України. 2010. № 2. С. 112-120.

11. Кулагін С.Л. Модели государственно-частного партнерства в экономическом механизме национального АПК: теория и методология. Весиі БДПУ. Серія 2. 2015. № 1. С. 69-73.

12. Вінокуров Я.О. Агенцію 3 питань державно-приватного партнерства запустять у 2019-му. URL: https://hromadske.ua/posts/nastupnogo-roku-v-ukrayini-zapustyat-agenciyu-yaka-zajmatimetsya-pitannyami-koncesiyi-minekonomiki.

13. Про торгово-промислові палати в Україні : Закон України від 17 березня 2020 р. № 671/97-ВР / Верховна Рада Украӥни. Відомості верховної Ради України. 1998. № 13. Ст. 52.

14. Комарницька Г.О. Вітчизняний досвід державно-приватного партнерства в умовах розвитку інвестиційно-інноваційної діяльності. Причорноморські економічні студї. 2019. Вип. 44. С. 43-48.

15. Стан здійснення державно-приватного партнерства в Україні. Міністерство розвитку економіки, торгівлі та сільського господарства України : офіційний сайт. URL: http://www.me.gov.ua/Documents/ Detail?lang=ukUA\&id=9fc90c5e-2f7b-44b2-8bf1- ffb7ee1be26\&title=StanZdiisnenniaDppVUkraini

16. Міцкан A.S/ Можливості ППП у сфері міського теплозабезпечення: механізми ЕСКО. Ялта, 2012. $20 \mathrm{c}$.

17. Комарницька Г.О. Напрямки активізування державно-приватного партнерства в умовах розвитку інвестиційно-інноваційної діяльності. Економіка та держава. 2019. № 5. 2019. С. 60-63.

\section{Prorochuk M.V. THE MECHANISM OF INTERACTION BETWEEN GOVERNMENT AND BUSINESS IN THE FIELD OF INFRASTRUCTURE}

The article considers the features of interaction between government and business in the field of infrastructure: identifies key players and tools of effective interaction between government and business: restoring the macroeconomic stability, ensuring sustainable economic growth in an environmentally friendly way, creating favorable conditions for business and transparent tax system. It is identified the main regulations of governing public-private partnership in Ukraine and the views of scientists on this category. It is revealed that the main forms of cooperation between the state and business are: concession, property management and joint activities on the basis of the agreement and the principles of project financing. The risks and benefits of joint interaction for government and business in the field of infrastructure are described. The basic models of interaction between government and business are listed: operator model, cooperation model, concession model, contractual model, leasing model. It is determined, that the main regulating documents of this relations are: Concept of Public-Private Partnership Development in Ukraine for 2013-2018 and the Memorandum of Interaction between the Ministry of Economic Development and the World Bank International Finance Corporation. It is indicated the number of projects in Ukraine by regions at the present stage, the total quantity is 187 agreements. It is studied the rating of top investors in domestic PPP projects for the last 15 years. 
The mechanism of interaction between government and business in the field of infrastructure was developed, which includes: subjects, stages, tools and new forms of interaction between government and business. It is investigated the problems and obstacles of PPP in modern conditions, as well as measures necessary for the development of the mechanism of interaction between government and business in the field of infrastructure: political and economic interest of the state; project development, thorough elaboration of contracts and financing opportunities; improving the legal and economic training of the executive branch, promoting their willingness to compromise and find ways to resolve emerging issues.

Key words: mechanism of interaction of power and business, public-private partnership, competitiveness of economy, sphere of infrastructure, tools of interaction, private sector, state. 